The key ends a series of wide-ranging introductory chapters. In these $\mathrm{Mr}$ Jubb discusses, among others, such diverse topics as fossil fishes in southern Africa, the physiographical and hydrobiological characteristics and history of the region, and the classification of fishes. There is also an introduction to fish anatomy with particular reference to characters used in the systematic section. Some of these chapters are much better than others; the main faults stem from the inevitable compression needed if so many different fields are to be covered at all. I believe that $\mathrm{Mr} \mathrm{Jubb}$ made the right decision in attempting this task. Too often the general reader is left in ignorance of the complex historical and environmental factors that have influenced, and still influence, the fishes which are his prime interest.

A map with the main rivers of southern Africa clearly labelled would be of great value to the reader unfamiliar with the country (the map provided shows only the most important drainage basins and is inadequate for detailed work), but the situation is alleviated by the excellent gazetteer of principal river systems (would that more authors should follow this practice). I would also criticize some of the imprecise definitions and minor inaceuracies in the anatomical section, particularly because these slips are likely to mislead the non-zoologist. For example, the circumorbital bones of a tigerfish are labelled "operculum" (Fig. 8), the premaxilla is labelled "maxillary" (Fig. 26), and the figure showing tooth-bearing bones in the jaws is rather imprecise. It must be emphasized, however, that these are but slight and easily rectified imperfections in an otherwise detailed and simply written guide to a complex subject.

Also included in the introductory section is an annotated check-list of southern African freshwater fishes. Synonymies are included, and so is information on the distribution of species (including indigenous species transferred into drainage basins to which they were not endemic). More detailed distribution lists are provided in a separate series of tables dealing with each of the main drainage systems. Taken together, these various analyses form an extremely valuable and unique compilation of data otherwise scattered through many sources, some now inaccurate and outdated.

The fourth, and final, section of the book deals with fishing methods, fish farming, angling, and the use of certain species in home aquaria and garden ponds. Much of this material is beyond my competence, but I would draw attention to the subsection on primitive fishing methods. Here, Mr Jubb has brought together much historical material and several unique photographs, all of which serve to illustrate and record a rapidly vanishing aspect of African culture. Taking his subject even further back in time, $\mathrm{Mr}$ Jubb also reviews the few but fascinating and somewhat enigmatic rock paintings from South Africa in which fishing scenes are depicted.

Freshwater Fishes of Southern Africa is a valuable contribution to the literature on African fishes, and its appearance will be welcomed by professional and amateur naturalists in many fields. Its place in the permanent literature of southern African natural history is assured; but, if future editions are to have the wide and popular use that the author's efforts and high standards so richly deserve, the publishers will have to bring down the price to a more realistic level.

P. H. Greenwood

\section{SOME PROTEIN TECHNIQUES}

\section{Techniques in Protein Chemistry}

By J. Leggett Bailey. Second, revised and expanded edition. Pp. xiv + 406. (Amsterdam, London and New York: Elsevier Publishing Company, 1967.) $110 s$.

THE mere fact that so specialized a book as this has required reprinting after two years and a second edition after five demonstrates clearly, by the hard test of sales, that it is of real value. There can be no doubt that the second edition will be just as useful and successful as the first.

The title of the book is a little misleading because it is not by any means an account of all the techniques used in protein chemistry. It is, rather, a detailed account of a selection of these techniques, notably those employing chromatographic procedures and useful for sequence studies on proteins. The first three chapters deal with the chromatographic and electrophoretic separation of aminoacids and peptides and the next four with methods used for sequence determination in proteins. There is then a chapter on dialysis and gel filtration (surely a rather illassorted pair), followed by two chapters on the column chromatography and zone electrophoresis of proteins. A short chapter on miscellaneous analytical methods is followed by a chapter, added in this edition, on the synthesis of simple peptides. I doubt whether this last chapter, good though it is, is of real relevance to the theme of the book; biochemists might well find it best to persuade their organic chemist colleagues to undertake any such syntheses for them.

The revision carried out for this second edition has been very thorough. About one-third of the thousand or so literature references are to papers published since 1960; very few relate to papers published since 1964. The book itself, despite pruning of older material, has also been expanded by about one third. There is, however, still some duplication and some further pruning might have been carried out with advantage; thus, for example, nearly all protein chemists nowadays use automatic amino-acid analysers and much of the third chapter seems irrelevant to current practice.

The book is well and clearly written. I found few errors, but there is a misleading one on page 23 ("nitrate" for "nitrite") and something has gone very wrong with the equations for the Akabori hydrazinolysis reaction (page 226).

These shortcomings are relatively minor blemishes on an excellent book. This is a work of real character and it is clear from every page that the author really knows what he is talking about. In his preface he hopes that the book will be "something handy to have in the laboratory"; it is much more than this, being an essential tool for everyone working in, or even only on the fringes of, the field of protein sequences. We shall all be looking for a third edition in a few years.

H. N. RYDON

\section{ACETYLENE COMES INTO ITS OWN}

\section{Acetylene}

Its Properties, Manufacture and Uses. Vol. 2. By S. A. Miller. Pp. xvii +406. (London: Ernest Benn, Ltd., 1966.) 126s. net.

THE appearance of the second volume of Dr Miller's work has been eagerly awaited. Not surprisingly, the large amount of chemistry to be covered has been found to necessitate a third volume and the present part covers only simple addition across the triple bond, leading largely to the industrially important vinyl compounds and halogen derivatives. Deferred until later are all reactions in which acetylene is used as a "building block" in organic synthesis, that is, ethynylation reactions, linear and cyclic polymerizations and carbonylation.

Since the first volume, debate about the relative merits of the old giant, acetylene, compared with ethylene as the optimum starting material for large tonnage chemical intermediates has continued. Some plans to use acetylene have been changed to the use of other feedstocks, but a number of manufacturers decided to opt for naphtha based acetylene processes, sometimes to replace carbide in order to continue to use existing equipment for often 